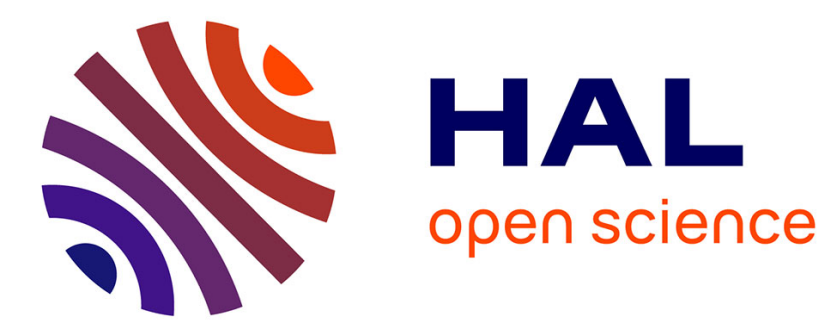

\title{
Multi-isotopic analysis of first Polynesian diet (Talasiu, Tongatapu, Kingdom of Tonga)
}

\author{
Estelle Herrscher, Jack N. Fenner, Frédérique Valentin, Geoffrey Clark, \\ Christian Reepmeyer, Laurie Bouffandeau, Guy André
}

\section{- To cite this version:}

Estelle Herrscher, Jack N. Fenner, Frédérique Valentin, Geoffrey Clark, Christian Reepmeyer, et al.. Multi-isotopic analysis of first Polynesian diet (Talasiu, Tongatapu, Kingdom of Tonga). Journal of Archaeological Science: Reports, 2018, 18, pp.308 - 317. 10.1016/j.jasrep.2018.01.012 . hal-01775314

\section{HAL Id: hal-01775314 \\ https://hal.science/hal-01775314}

Submitted on 27 Apr 2018

HAL is a multi-disciplinary open access archive for the deposit and dissemination of scientific research documents, whether they are published or not. The documents may come from teaching and research institutions in France or abroad, or from public or private research centers.
L'archive ouverte pluridisciplinaire HAL, est destinée au dépôt et à la diffusion de documents scientifiques de niveau recherche, publiés ou non, émanant des établissements d'enseignement et de recherche français ou étrangers, des laboratoires publics ou privés. 


\title{
Multi-isotopic analysis of first Polynesian diet (Talasiu, Tongatapu, Kingdom of Tonga)
}

\author{
Estelle Herrscher ${ }^{\mathrm{a}, *}$, Jack N. Fenner ${ }^{\mathrm{b}}$, Frédérique Valentin ${ }^{\mathrm{c}}$, Geoffrey Clark ${ }^{\mathrm{b}}$, \\ Christian Reepmeyer ${ }^{\mathrm{d}}$, Laurie Bouffandeau ${ }^{\mathrm{e}}$, Guy André ${ }^{\mathrm{a}}$ \\ a Aix Marseille Univ, CNRS, Minist Culture, LAMPEA, Aix-en-Provence, France \\ ${ }^{\mathrm{b}}$ Dpt of Archaeology and Natural History, College of Asia and the Pacific, The Australian National University, Canberra, Australia \\ ${ }^{\mathrm{c}}$ UMR 7041-ArScAn-Ethnologie Préhistorique, CNRS, Nanterre, France \\ ${ }^{\mathrm{d}}$ College of Arts, Society and Education, James Cook University, Cairns, Australia \\ e Université de Polynésie Française, CIRAP, Tahiti, French Polynesia
}

\section{A R T I C L E I N F O}

\section{Keywords:}

Pacific

Lapita

Diet

Stable isotopes

Collagen

Apatite

\begin{abstract}
A B S T R A C T
Both archaeological and isotopic data document dietary changes over the first five centuries of Western Pacific island settlement, a time period beginning with the Lapita expansion about 3000 years ago. This change is marked by a decrease in marine food intake and an increase in vegetal food intake occurring in the Late Lapita/ immediately post-Lapita populations. The recent discovery of human burials at Talasiu $(\sim 2700-2600 \mathrm{cal}$. BP $)$ in the Kingdom of Tonga opens new opportunities to assess this matter. We characterize the nature of the food items consumed by the Talasiu humans $(n=21)$ using collagen and apatite carbon and nitrogen stable isotope ratios. We conducted an intra-Pacific comparison to examine the use of marine resources and the contribution of horticultural products and to look at the homogeneity of dietary practices within the Tongan group. Isotope results indicate a mixed diet of terrestrial and marine resources including a differential contribution of more specific marine foods (e.g., non-reef fish/inshore fish and shellfish). The Talasiu dietary pattern appears closer to that of the early Lapita population of Teouma than to other Late Lapita populations suggesting a different pattern of dietary change at the eastern end of the Lapita distribution. The slower rate of change may be due to the small size of both the island and the population, and also the additional potential role of social or cultural factors.
\end{abstract}

\section{Introduction}

Colonization causes new connections and relationships between migrating humans and their cultural and natural environments that can be examined through studying dietary change (Twiss, 2012). Originating from South-East Asia, the first settlers of the Pacific region east of the Solomon archipelago are associated with the Lapita culture that appeared about 3300 years ago in north Melanesia (Summerhayes et al., 2010; Skoglund et al., 2016; Valentin et al., 2016). These original colonizers are generally regarded as people with a mixed subsistence economy that combined the exploitation of marine resources with a low level of terrestrial resource production based on chicken or pig husbandry and taro cultivation (Groube, 1971; Burley, 1999; Kirch, 2002; Kennett et al., 2006). In less than 500 years after the first arrivals in the pristine islands, food resources used by humans appear to have largely changed. Consumption of wild terrestrial and marine foods decreased and the agricultural component of the diet increased (Davidson et al., 2002; Kirch, 2002; Anderson, 2009; Sheppard, 2011). A declining mid-
Holocene sea level and human-induced landscape alteration including deforestation and faunal extinctions have been identified as potential driving forces that -coupled with an increasing emphasis on the products of horticulture- caused significant dietary change between the beginning and the end of the Lapita period (Clark and Anderson, 2009; Cochrane et al., 2011; Sheppard, 2011). From a dietary change perspective there are three issues in our understanding of Lapita subsistence that require investigation: (1) what was the balance between native animal, plant and marine foods and introduced foods, especially tuber crops?, (2) did the shift toward horticultural foods occur soon after colonization everywhere in the Pacific?, and (3) what influence did population size and mobility have on these processes?

Stable isotope studies, applied to skeletal remains of early Pacific populations, have shown a trend toward a horticultural diet with temporal variation in response to local environmental conditions (Field et al., 2009; Kinaston and Buckley, 2013; Valentin et al., 2010, 2014; Kinaston et al., 2014, 2015, 2016). As a consequence, human groups associated with the late-Lapita/immediately post-Lapita period are

\footnotetext{
* Corresponding author.

E-mail address: herrscher@mmsh.univ-aix.fr (E. Herrscher).
} 


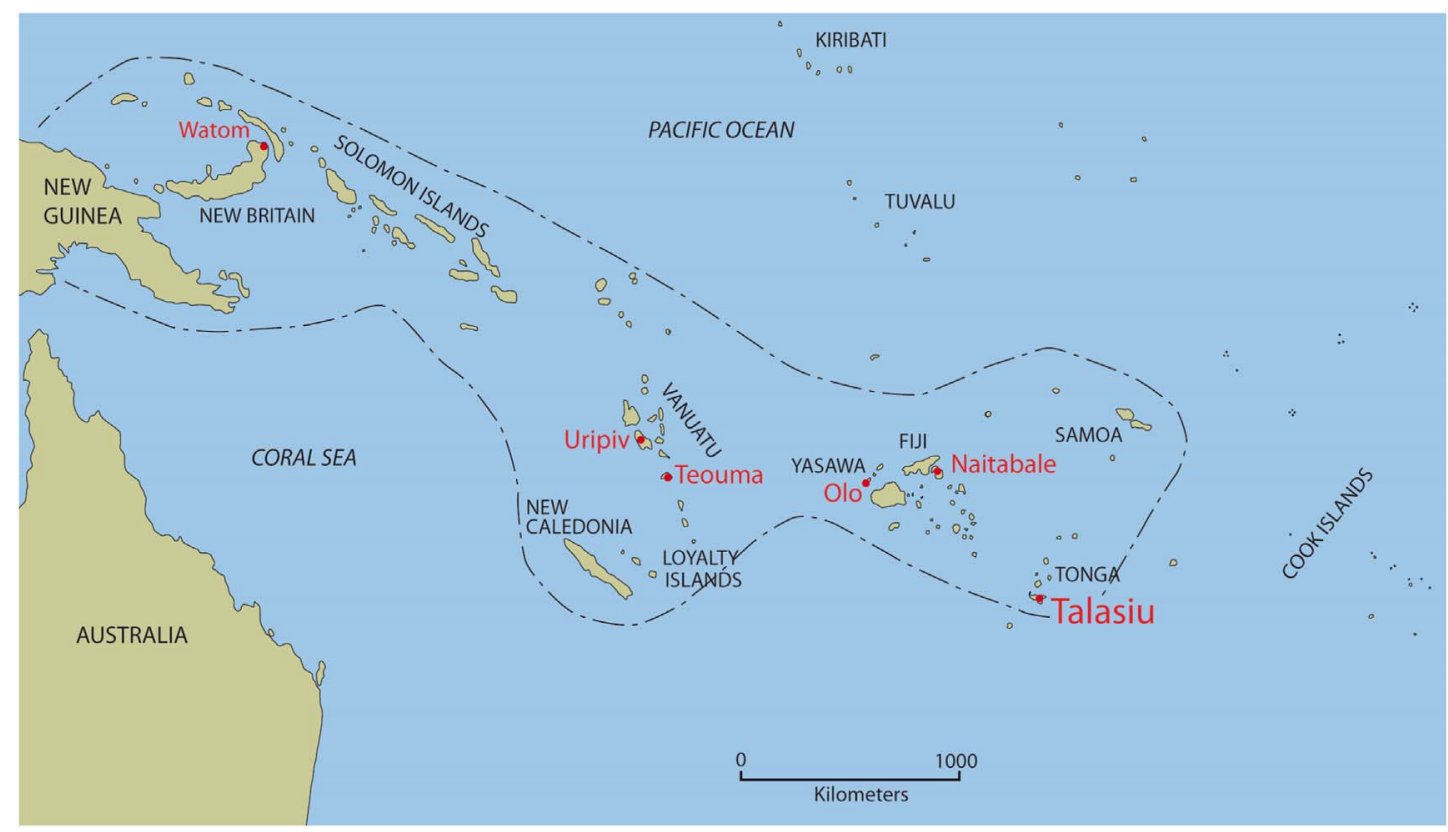

Fig. 1. Lapita expansion and Pacific archaeological sites considered in this study.

expected to have stable isotope ratios indicating that fewer marine resources were consumed compared with the first Lapita colonizers. We expect that post-colonization groups should have: (1) lower collagen stable carbon and nitrogen isotope ratios suggesting a higher terrestrial animal intake; (2) lower apatite stable carbon isotope ratios indicating an increased reliance on food items with a higher carbohydrate content such as taro and other cultivated plants and, (3) a lower dispersion of collagen and apatite stable isotope ratios reflecting adoption of a dietary standard based on terrestrial resources. These assumptions are examined here through multiple stable isotope analyses, including results from new human collagen and apatite bone samples $(n=21)$ obtained on early Polynesians people from the Talasiu site (Kingdom of Tonga) and their comparison with isotope results from other parts of the Pacific.

\section{Talasiu site}

The Talasiu site (TO-Mu-2) is located on the palaeoreef-limestone shoreline of the Fanga 'Uta Lagoon, north of Lapaha Village, only $2.5 \mathrm{~km}$ south of Nukuleka Village which is regarded as the place of the initial Lapita landfall in Tonga (Burley et al., 2010) (Fig. 1). The site consists of a dense shell midden deposit $\sim 90 \mathrm{~cm}$ thick covering some 450 square meters. This midden contains large numbers of bivalves, mixed with pot sherds, charcoal, bone, and shell and stone artifacts, but no fishing gear except perhaps for tiger cowrie caps (Cypraea tigris) that have been considered parts of a composite octopus lure rig (Poulsen, 1987, for a critical discussion of these artifacts see Spennemann, 1993; Best, 1984: 459), and perforated Anadara sp. shells that are sometimes thought to be net weights (but see Connaughton et al., 2010). The pottery is predominantly plain with some dentate-stamped vessels bearing simple open designs typical of late Lapita ceramics. Shell artifacts include short and long shell units, broad Conus spp. rings, narrow rings made of Conus spp. and Tridacna spp., and small circular flat beads that are similar to Lapita ornaments. Lithics items comprise adzes, flakes, grinding stones and oven stones whose raw material has a distinct geographical source with obsidian from northern Tonga and lithics from 'Eua (south Tonga), Samoa, east Fiji and volcanic islands within Tonga, suggesting significant population mobility (Reepmeyer et al., 2012; Clark et al., 2014). The deposit also includes features, such as 'hearths, ovens, oven rake outs, and burials, placed at the base of the deposit or interstratified within the midden.

The $95 \%$ probability range of radiocarbon determinations obtained on coconut endocarp, unidentified charcoal, worked shell grave goods and human bone samples fall between 2750 and 2150 cal. BP (Valentin and Clark, 2013; Clark et al., 2015; Skoglund et al., 2016) (Table 1). Calibrated charcoal and bone ${ }^{14} \mathrm{C}$ ages between 2600 and $2300 \mathrm{BP}$ are

Table 1

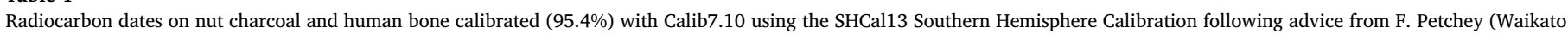
Radiocarbon Dating Laboratory, Waikato University). Marine shellfish ages calibrated with Marine13 and Delta R set at $11 \pm 83$ years after Petchey and Clark (2011).

\begin{tabular}{|c|c|c|c|c|c|}
\hline Lab number & Unit and depth & Material & $\begin{array}{l}\text { Conventional radiocarbon age (CRA) } \\
{ }^{14} \mathrm{C} \text { age and error (BP) }\end{array}$ & $\delta^{13} \mathrm{C}(\% 0)$ & Calibrated age $95.4 \%$, cal. BP \\
\hline Wk-22999 & TP.1: $40 \mathrm{~cm}$ & Tridacna sp.: grave good & $2767 \pm 37$ & $2.2 \pm 0.2$ & $2291-2720$ \\
\hline Wk-23000 & TP.1: $65 \mathrm{~cm}$ & Tridacna sp.: grave good & $2726 \pm 30$ & $2.8 \pm 0.2$ & $2210-2695$ \\
\hline Wk-23001 & TP.1: $80 \mathrm{~cm}$ & Conus sp.: grave good & $2682 \pm 30$ & $3.5 \pm 0.2$ & $2150-2660$ \\
\hline Wk-25461 & TP.1: $40-65 \mathrm{~cm}$ & Human bone (burned): bone concentration & $2499 \pm 31$ & $-12.2 \pm 0.2$ & $2360-2700$ \\
\hline Wk-41883 & TP.A2 & Human bone: Sk10 fibula & $2594 \pm 20$ & $-16.4 \pm 0.2$ & $2340-2680$ \\
\hline Wk-22876 & TP.1: $91 \mathrm{~cm}$ & Charcoal from F6: structure & $2452 \pm 30$ & $-23.5 \pm 0.2$ & $2350-2700$ \\
\hline Wk-23002 & TP.1: $80 \mathrm{~cm}$ & Charcoal from F5: structure & $2562 \pm 30$ & $-25.0 \pm 0.2$ & $2490-2750$ \\
\hline Wk-28234 & TP.1: $55-60 \mathrm{~cm}$ & Carbonized coconut endocarp: shell midden & $2473 \pm 31$ & $-21.3 \pm 0.2$ & $2350-2700$ \\
\hline Wk-28235 & TP.1: $70-75 \mathrm{~cm}$ & Carbonized coconut endocarp: shell midden & $2510 \pm 30$ & $-21.3 \pm 0.2$ & $2380-2720$ \\
\hline Wk-33572 & TP.2: Spit $4,15-20 \mathrm{~cm}$ & Carbonized coconut endocarp: shell midden & $2533 \pm 25$ & $-22.6 \pm 0.2$ & $2440-2740$ \\
\hline Wk-33573 & TP.2: Spit $11,50-55 \mathrm{~cm}$ & Carbonized coconut endocarp: shell midden & $2448 \pm 25$ & $-22.5 \pm 0.2$ & $2360-2690$ \\
\hline Wk-33574 & TP.2: Spit $18,85-90 \mathrm{~cm}$ & Carbonized coconut endocarp: shell midden & $2504 \pm 25$ & $-23.0 \pm 0.2$ & $2380-2710$ \\
\hline
\end{tabular}


Table 2

Archaeological, anthropological and collagen and carbonate apatite elemental and isotope ratios for Talasiu humans and animals.

\begin{tabular}{|c|c|c|c|c|c|c|c|c|c|c|c|c|}
\hline Burial & Ind. ID & Age & Sex/age & Skeletal element & Yield $\left(\mathrm{mg} \cdot \mathrm{g}^{-1}\right)$ & $\% \mathrm{C}$ & $\% \mathrm{~N}$ & $\mathrm{C} / \mathrm{N}$ & $\delta^{13} \mathrm{C}_{\text {col }}(\% 0)$ & $\delta^{15} \mathrm{~N}(\% 0)$ & $\mathrm{CaCO}_{3} \%$ & $\delta^{13} \mathrm{C}_{\mathrm{ap}}(\%)$ \\
\hline BG2 & BG2 & Adult & $\mathrm{F}$ & L femur & 20.3 & 32.9 & 10.2 & $\underline{3.8}$ & -17.5 & 11.8 & & \\
\hline BG3 & BG3 & Adult & $\mathrm{F}$ & $\mathrm{R}$ humerus & 23.2 & 35.0 & 12.8 & $\overline{3.2}$ & -16.0 & 11.4 & $\underline{2.8}$ & -10.3 \\
\hline Sk1 & Sk1 & Adult & $\mathrm{F}$ & $\mathrm{R}$ femur & 10.2 & 33.8 & 12.1 & 3.2 & -16.2 & 10.8 & $\overline{5.8}$ & -10.9 \\
\hline Sk2 & Sk2.1 & Adult & Unknown & R tibia & 10.9 & 30.6 & 11.0 & 3.2 & -15.9 & 10.8 & $\underline{7.1}$ & -10.0 \\
\hline Sk2 & Sk2.2 & Adult & M & $\mathrm{R}$ tibia & 11.9 & 41.0 & 14.8 & 3.2 & -15.8 & 11.9 & 5.2 & -9.6 \\
\hline Sk2 & Sk2.4 & Adolesc. & 12-16 years & L femur & 13.7 & 30.6 & 11.2 & 3.2 & -15.8 & 9.4 & 6.5 & -9.9 \\
\hline Sk3 & Sk3.1 & Adult & $\mathrm{F}$ & L femur & 20.1 & 37.0 & 14.1 & 3.0 & -15.6 & 8.8 & 6.7 & -10.0 \\
\hline Sk3 & Sk3.2 & Adult & M & $\mathrm{R}$ tibia & 10.3 & 34.4 & 11.7 & 3.4 & -16.5 & 10.3 & 5.7 & -10.3 \\
\hline Sk5 & Sk5 & Adult & M & $\mathrm{R}$ femur & $10.6^{*}$ & $\underline{22.2}$ & $\underline{6.8}$ & $\underline{3.8}$ & -17.2 & 10.5 & & \\
\hline Sk7 & Sk7.1 & Adult & Unknown & R Tibia (n $\left.{ }^{\circ} 1 / 9\right)$ & 17.5 & $\underline{6.9}$ & $\underline{2.0}$ & $\overline{3.9}$ & -16.2 & 10.0 & & \\
\hline Sk7 & Sk7.2 & Adult & Unknown & L Humerus $\left(n^{\circ} 3\right)$ & $\underline{8.7}$ & $\overline{32.3}$ & $\overline{11.5}$ & $\overline{3.3}$ & -15.0 & 11.2 & & \\
\hline Sk9 & Sk9.1 & Child & $7-11$ years & L humerus & 19.2 & 38.1 & 13.9 & 3.2 & -15.1 & 10.4 & 6.9 & -9.0 \\
\hline Sk9 & Sk9.2 & Adult & Unknown & R ulna & 14.3 & 30.7 & 11.1 & 3.2 & -16.0 & 10.9 & $\underline{8.3}$ & -9.5 \\
\hline Sk9 & Sk9.3 & Adult & Unknown & $\mathrm{R}$ radius & 44.8 & 39.3 & 14.2 & 3.2 & -16.1 & 10.4 & $\overline{8.4}$ & -10.5 \\
\hline Sk10 & Sk10 & Adult & $\mathrm{F}$ & R tibia & 15.5 & 34.8 & 12.3 & 3.3 & -16.2 & 10.3 & $\overline{7.3}$ & -10.5 \\
\hline Sk11 & Sk11 & Child & $1.5-2.5$ years & Mandible & 20.2 & 36.0 & 13.1 & 3.2 & -14.0 & 12.1 & $\overline{7.2}$ & -10.5 \\
\hline Sk12 & Sk12.1 & Adult & Unknown & $\mathrm{R}$ femur & 20.7 & 31.1 & 11.1 & 3.2 & -15.5 & 10.8 & $\overline{6.6}$ & -9.8 \\
\hline Sk13 & Sk13 & Child & 1.5-2.5 years & $\mathrm{R}$ femur & $24.4^{* *}$ & $\underline{17.5}$ & 5.4 & 3.7 & -15.4 & 13.4 & & \\
\hline Sk14 & Sk14 & Adult & M & $\mathrm{R}$ femur & $14.7^{*}$ & $\overline{29.2}$ & $\overline{10.3}$ & $\overline{3.3}$ & -16.4 & 11.4 & $\underline{7.1}$ & -10.7 \\
\hline Sk16 & Sk16 & Adult & $\mathrm{F}$ & $\mathrm{R}$ coxal & 33.2 & 32.4 & 11.3 & 3.3 & -16.8 & 11.2 & $\overline{7.5}$ & -10.0 \\
\hline \multirow[t]{6}{*}{ Sk17 } & Sk17 & Adult & Unknown & Femur & 29.5 & 35.4 & 12.6 & 3.3 & -14.0 & 11.0 & $\underline{10.2}$ & -11.0 \\
\hline & & & & $\mathrm{N}($ valid) & 16 & 16 & 16 & 16 & 16 & 16 & 7 & 7 \\
\hline & & & & Mean & 19.5 & 34.3 & 12.4 & 3.2 & -15.7 & 10.7 & 6.2 & -9.9 \\
\hline & & & & Min & 10.2 & 29.2 & 10.3 & 3.0 & -16.8 & 8.8 & 5.2 & -10.9 \\
\hline & & & & Max & 44.8 & 41.0 & 14.8 & 3.4 & -14.0 & 12.1 & 6.9 & -9.0 \\
\hline & & & & $\mathrm{SD}$ & 9.5 & 3.4 & 1.4 & 0.1 & 0.8 & 0.8 & 0.6 & 0.6 \\
\hline TPH2 & Animal & Pig & & Mandible & 18.4 & 33.3 & 12 & 3.2 & -19.6 & 7.4 & & \\
\hline TPI2 & Animal & Pig & & Mandible & 45.2 & 39.5 & 14.2 & 3.2 & -19.8 & 8.3 & & \\
\hline
\end{tabular}

Protocol: *: 2nd attempt with a reduced soak in $\mathrm{NaOH}$, only $2 \mathrm{~h}$; **: 3rd attempt $\mathrm{HCl}$ at cold temperature for several days on chunk bones (SD1).

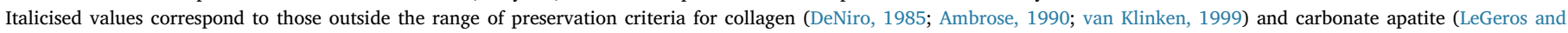
LeGeros, 1984). All these samples are excluded from the discussion and the graphs.

strongly influenced by curve flattening resulting in multiple curve intercepts and a substantial widening in the calibrated age range of determinations. However, a high-resolution chronology based on Uranium-Thorium (U-Th) dating of coral files and Accelerator Mass Spectrometry (AMS) dating on short-lived material demonstrates the Lapita period on Tongatapu spanned $2850-2650$ cal. BP (64.2\% prob) (Burley et al., 2015) and it is highly likely that the midden and burials at Talasiu date to $\sim 2700-2600 \mathrm{cal}$. BP and are of late Lapita/immediately post-Lapita age.

During the Lapita period in Tonga, the Talasiu site would have been an attractive location for human settlement as it overlooked an embayment holding large numbers of sessile and gregarious shellfish close to a fresh water solution channel, with gardening soils immediately inland. However, sea levels were declining from a mid-Holocene high stand in the western Pacific (Nunn and Carson, 2015) and, in Tongatapu, sea level fall led to the closure of the Fanga 'Uta Lagoon passage at the high-tide level by $\sim 2500$ cal. BP (Ellison, 1988; Spennemann, 1997). The consecutive transformations over centuries of near-shore environments and coastal ecology may have reduced the productivity of littoral marine zones and shaped the Talasiu population subsistence economy. Analysis of the Talasiu midden contents using archaeozoological and microbotanical techniques provided evidence for a mixed economy in which the cropping horticultural component supplemented, and perhaps may have equaled, the contribution of marine food (Clark et al., 2015). Exploitation of marine resources is characterized by the harvesting/gathering of three main species of bivalve (Dendostrea cf. folium, Anadara antiquata, Gafrarium tumidum that comprise $72 \%$ of the total Number of Identified Specimens - NISP) from the intertidal zone, occasional turtle, and a significant number of inshore reef fishes. A recent study of fish bones from the northern part of the site (number of remains $=1307$ ) confirms the capture of small individuals showed by Clark et al. (2015) although taxonomic analysis of all anatomical elements, including the vertebrae, reveals a wide range of taxa (24 families of teleosts) (L. Bouffandeau, unpublished data). This is a high diversity, in comparison to the six families identified by Clark et al. (2015) that might result from differences in methodological approaches or from contextual/functional intra-site variations. No remains of extinct fauna such as land birds and giant iguana were found at the site (Clark et al., 2015), and terrestrial animals are represented by only a few remains of chicken (Gallus gallus) and rat (Rattus exulans). These two species were introduced at the start of colonization in contrast to the pig (Sus scrofa) and dog (Canis familiaris) which appear to have been imported to Tonga much later in time (Clark et al., 2013). Terrestrial vegetal resources were identified through starch grains extracted from Talasiu midden sediments (Ussher, 2015), and comprised indigenous species as well as eight imported species including core cultigens: common taro (Colocasia esculenta), giant swamp taro (Cyrtosperma merkusii), common yam (Dioscorea alata) and banana (Musa spp.), indicating the development of horticulture. Other Lapita edible plant introductions including cabbage palm (Cordyline fruticosa, rhizome), and island lychee (Pometia pinnata, fruit), are documented for Tonga via palynology study. Pollen increases in indigenous species such as Canarium (Canarium harveyi, nut), coconut palm (Cocos nucifera, nut) and screwpine (Pandanus tectorius, fruit) suggest their cultivation for dietary consumption (Fall, 2010; Fall and Drezner, 2013).

\section{Material}

Nineteen late-Lapita/immediately post-Lapita burial contexts contemporary with the midden were identified at Talasiu. The contexts were single or multiple interments containing the skeletal remains of one to six individuals, including adults and subadults. Subadult age at death was assessed using dental and skeletal criteria (Ubelaker, 1989; Scheuer and Black, 2000). Adult sex was estimated based on the morphology of os coxa (Bruzek, 2002) and skull (Ferembach et al., 1979). Field evidence indicates a wide range of mortuary practices involving 
primary burial in various positions, post-decomposition removal of skulls and long bones, and secondary deposits of heated (Valentin and Clark, 2013) or unheated bone, as well as secondary deposit of isolated skulls. Human skeletal remains of at least 45 individuals were identified in and around these 19 burial contexts while a few other bones were found dispersed within the midden layers.

The best preserved individuals were selected for isotope analysis of diet (Table 2). These represent 21 individuals including four subadults: two young children aged between 1.5 and 2.5 years old, one child between 7 and 11 years old and one adolescent (12-16 years old), and 17 adults including six females, four males and seven adults whose sex was undetermined.

\section{Methods}

Protein food intake may be reconstructed by means of stable carbon and nitrogen isotope ratios in human bone collagen $\left(\delta^{13} \mathrm{C}_{\mathrm{col}}\right.$ and $\left.\delta^{15} \mathrm{~N}\right)$. Stable carbon isotope ratios allows detection in human diet of the proportion of C4-plants versus C3-plants (Katzenberg et al., 1995) and the proportion of marine versus terrestrial resources (Schoeninger and DeNiro, 1984) whereas stable nitrogen isotope ratios allow a more direct quantitative estimation of the protein contribution (O'Connell and Hedges, 1999; Fernandes et al., 2014). Theoretical nitrogen isotope fractionation may vary from 3 to $6 \%$ between food and consumer (Bocherens and Drucker, 2003; O'Connell et al., 2012) while carbon isotope fractionation is only $+0-2 \%$ (Bocherens and Drucker, 2003) between food and consumer. Collagen carbon isotope ratios also include a $+5 \%$ offset due to fractionation during carbon incorporation into collagen. Stable carbon isotope ratios in human bone hydroxyapatite (or apatite, $\delta^{13} \mathrm{C}_{\mathrm{ap}}$ ), on the other hand, reflect the total diet including carbohydrates and lipids as well as protein and thus can be used to assess non-protein sources in the diet, particularly plant consumption (Ambrose and Norr, 1993; Schwarcz, 2000; Kellner and Schoeninger, 2007; Fernandes et al., 2014). Estimates of carbon isotope fractionation between diet and bone apatite range from 9.5 to $13 \%$ (Howland et al., 2003; Tykot et al., 2009; Warinner and Tuross, 2009; Fernandes et al., 2012); we adopt an offset of 10\% (Fernandes et al., 2012). Our overall conclusions would not change substantially if a different value in this range were used.

In such theoretical context, merging stable isotope data from both collagen and apatite appears to be theoretically fruitful in the Pacific islands context, where the consumption of low trophic level items like plants (tubers, fruits) and inshore resources (algae, shellfish) characterized human diet (Katzenberg, 2008; Schoeninger, 2010). Carbon stable isotope ratios from collagen are used to identify the consumption of proteins sourced from terrestrial environments versus those sourced from marine environments (Schoeninger and DeNiro, 1984; DeNiro and Epstein, 1978). Collagen nitrogen isotope ratios decipher the consumption of non-reef fish and animal meat from the consumption of horticultural plants and inshore food resources like algae, shellfish, crustacean, and coral reef fish (DeNiro and Epstein, 1981; Schoeninger et al., 1983). Carbon stable isotope ratios from apatite carbonate highlight the consumption of carbohydrate or lipid rich resources such as taro and yam versus $\mathrm{C}_{4}$-plants and inshore resources (Ambrose et al., 1997). In the Pacific Island context, sulfur stable isotope ratios of collagen are of limited interest owing to the sea spray effect (Kinaston et al., 2014).

While carbon and nitrogen stable isotope ratios measured in bone collagen are routinely employed to reconstruct prehistoric human diets of Pacific populations, particularly so because preservation indicators are well documented (DeNiro, 1985; Ambrose, 1990; van Klinken, 1999), the use of apatite carbon isotope ratios has been challenged because there are no unanimously recognized methods for assessing its preservation (Zazzo, 2014). Some researchers have used Fouriertransform infrared spectroscopy (FTIR) and a crystallinity index to assess alterations in crystal structure of the apatite (Wright and Schwarcz,
1996). Others have proposed a comparison of phosphate and carbonate isotope ratios or the amount of $\mathrm{CO}_{2}$ extracted from each sample to identify possible diagenetic alteration (Iacumin et al., 1996, 2014). In a study of Maya human bones from Belize, researchers used $\mathrm{CO}_{2}$ gas yield produced during the combustion of apatite samples in the mass spectrometer (Williams et al., 2005), accepting the range of $\mathrm{CO}_{2}$ yields between 0.6 and $1.3 \%$ as indicative of unaltered samples (Ambrose, 1993). In the only relevant study of the preservation of apatite carbonate stable isotope ratios in the Pacific area, Ambrose et al. (1997) examined diagenetic effects in bone from the Marianas by the means of assessing correlation between carbonate carbon concentration $(\% \mathrm{C})$ and $\delta^{13} C_{a p}$. Specifically, the correlation of these two values would indicate diagenetic apatite carbonate (Ambrose et al., 1997). More recently, Salesse et al. (2014) conducted a detailed analysis of diagenetic effects on isotope signatures (collagen/apatite carbonate) in bones excavated under controlled environmental conditions in a temperate region (Catacomb, Roma, $\mathrm{I}^{\text {st }}$-III ${ }^{\text {rd }} \mathrm{C}$ AD). Using established collagen criteria $(\% \mathrm{C}, \% \mathrm{~N}, \mathrm{C}: \mathrm{N})$, infrared spectroscopy and radiocarbon dating of collagen-carbonate pairs, the authors demonstrated that where the preservation of the organic phase of the bone was poor, samples with high rates of recrystallisation in hydroxyapatite do not show significant isotopic exchanges (Salesse et al., 2014). Interestingly, similar results were also obtained in studies from tropical environments (Zazzo et al., 2014). These studies suggest that, in addition to the routine use of collagen stable isotope ratios for past dietary reconstructions in the Pacific area, stable isotope data from apatite carbonate have the potential to provide useful insights.

Stable carbon and nitrogen isotope ratios in bone collagen and carbon isotope ratios in bone apatite data were obtained by the means of the techniques described in supplementary data (SD1). For collagen, standard indicators have been used to assess its preservation, such as collagen yield, carbon and nitrogen contents and carbon to nitrogen atomic ratios (DeNiro, 1985; Ambrose, 1990; van Klinken, 1999) (SD1). As no universally accepted criteria exist to evaluate apatite preservation (Zazzo, 2014; Salesse et al., 2014), we use samples with good collagen preservation because the organic matrix may involve both better protection of the bioapatite and lower isotope exchange with water ( $\mathrm{Hu}$ et al., 2006; Iacumin et al., 2014). In addition to gaining insight on potential carbonate diagenesis, the excess carbonate carbon was evaluated thanks to the calcium carbonate content $\left(\mathrm{CaCO}_{3} \%\right)$ and the homogeneity of the apatite carbonate carbon isotope values was assessed based on the correlation between $\mathrm{CaCO}_{3} \%$ and $\delta^{13} \mathrm{C}_{\mathrm{ap}}$ (Ambrose et al., 1997) as well as between $\delta^{13} \mathrm{C}_{\mathrm{ap}}$ and $\delta^{13} \mathrm{C}_{\text {col }}$ (Lee-Thorp and Sponheimer, 2003; Pechenkina et al., 2005), in both cases using the Spearman correlation test.

Our dietary reconstruction relies primarily on collagen data. Considering the impact of local environment on the stable isotope ratios of foodwebs (Herrscher and Le Bras-Goude, 2010; Drucker and HenryGambier, 2005; Kinaston et al., 2014), specific attention was paid to characterize the stable carbon and nitrogen isotope ratios of potential food items available in the local environment of the studied population. Such a preliminary investigation is of great importance in interpreting with reliability the human isotope values and when identifying the dietary resources which were preferentially eaten. In the island ecosystem of this study, since no other animal isotope values are currently published for Tonga (Wong, 2014; Stantis et al., 2015), our interpretation uses published data corresponding to 440 stable carbon isotope ratios and 408 nitrogen isotope ratios (Table 3). Most of them are from modern specimens, except for terrestrial animals including two pigs from the Talasiu site analyzed as part of this investigation that were uncovered in a later pit disturbing the west edge of the midden deposits and directly dated to $300-280 \mathrm{cal}$. BP, and the prehistoric marine turtles from Teouma (Kinaston et al., 2014). Dietary resources were divided into nine groups corresponding to three trophic levels (Table 3, Fig. 2). The lowest trophic level comprises terrestrial $\mathrm{C}_{3}$ and $\mathrm{C}_{4}$ plants as well as "coastal products", i.e. inshore resources such as 
Table 3

Isotope variability of the main type of dietary resources from Pacific area.

\begin{tabular}{|c|c|c|c|c|c|c|c|c|c|c|c|c|}
\hline \multirow[t]{2}{*}{ Dietary resources } & \multicolumn{6}{|c|}{$\delta^{13} \mathrm{C}(\%)$} & \multicolumn{6}{|c|}{$\delta^{15} \mathrm{~N}(\% 0)$} \\
\hline & $\mathrm{n}$ & Mean & Min & $\operatorname{Max}$ & SD & Var & $\mathrm{n}$ & Mean & Min & $\operatorname{Max}$ & SD & Var \\
\hline Coastal products ${ }^{\mathrm{e}}$ & 50 & -11.3 & -28.1 & -0.2 & 5.5 & 29.9 & 50 & 3.9 & 9.5 & 10.7 & 3.0 & 9.0 \\
\hline Terrest. C3 plants ${ }^{\mathrm{e}}$ & 110 & -25.0 & -30.1 & -20.9 & 2.1 & 4.6 & 96 & 4.0 & 1.3 & 9.8 & 2.3 & 5.2 \\
\hline Terrest. C4 plants & 7 & -10.5 & -11.2 & -9.4 & 0.7 & 0.4 & 5 & 4.7 & 3.2 & 8.4 & 2.2 & 4.8 \\
\hline Coral reef fish ${ }^{\mathrm{a}}$ & 59 & -12.3 & -19.3 & -2.8 & 2.9 & 8.3 & 53 & 8.4 & 3.2 & 14.0 & 2.1 & 4.3 \\
\hline Non reef fish ${ }^{e}$ & 26 & -14.5 & -20.7 & 0.9 & 3.7 & 13.9 & 16 & 12.6 & 7.1 & 16.0 & 2.6 & 6.9 \\
\hline Freshwater ${ }^{\mathrm{e}}$ & 10 & -20.1 & -25.2 & -16.9 & 2.7 & 7.5 & 10 & 6.5 & 0.9 & 10.5 & 3.8 & 14.7 \\
\hline Marine mammals ${ }^{\mathrm{b}}$ & 81 & -13.1 & - & - & 1.0 & - & 81 & 14.9 & - & - & 2.9 & - \\
\hline Marine turtle $e^{c}$ & 2 & & -17.4 & -9.9 & & & 2 & & 13.0 & 14.9 & & \\
\hline Terrestrial animals ${ }^{\mathrm{d}}$ & 174 & -18.7 & -27.7 & -10.1 & 2.9 & 8.7 & 174 & 9.5 & 0.8 & 18.3 & 3.7 & 13.4 \\
\hline
\end{tabular}

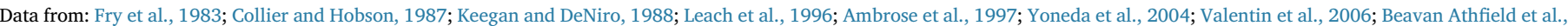
2008; Field et al., 2009; Allen and Craig, 2009; Jones and Quinn, 2009; Richards et al., 2009; White et al., 2010; Valentin et al., 2010 ; Storey et al., 2010 ; Kinaston et al., 2014.

a Only 1 archaeological specimen from Valentin et al., 2010.

b All data from Yoneda et al., 2004, on 81 bone collagen samples.

c Only 2 archaeological specimens from Kinaston et al., 2014.

d All specimens are archaeological except 10 moderns from Ambrose et al., 1997, Valentin et al., 2006, Beavan Athfield et al., 2008 , Kinaston et al., 2014.

e All samples are modern ones.

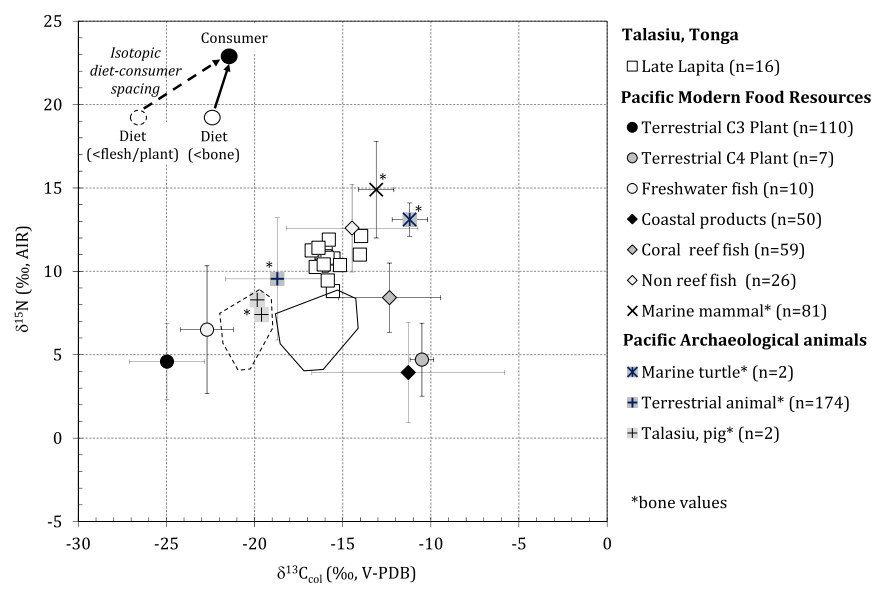

Fig. 2. $\delta^{13} \mathrm{C}_{\text {col }}$ and $\delta^{15} \mathrm{~N}$ values for Talasiu humans compared to Pacific food resources baseline. (Modern $\delta^{13} \mathrm{C}$ values: pollution corrected by $+1.5 \%$ / $+0.86 \%$ for terrestrial and marine resources respectively: for references see Table 3 ).

shellfish and algae. The intermediate trophic level consists of fish with coral reef fish, non-reef fish and freshwater fish. The highest level corresponds to marine mammals and turtles as well as terrestrial animals. All modern specimens were corrected for ${ }^{13} \mathrm{C}$ enrichment due to fossil fuel emissions, adding $+0.86 \%$ for marine individuals and $+1.5 \%$ for terrestrial ones (Kinaston et al., 2014).

Stable isotope data on apatite was considered as a complementary proxy for diet reconstruction and used in the dietary model proposed by Kellner and Schoeninger (2007), then modified following Froehle et al. (2010) and corrected following Eerkens et al. (2013). This model is a mono-isotopic model, based on carbon proxies $\left(\delta^{13} \mathrm{C}_{\mathrm{col}}\right.$ and $\left.\delta^{13} \mathrm{C}_{\mathrm{ap}}\right)$. Using experimental animal data under controlled diet, both stable isotope ratios are projected on two regression lines $\left(C_{3}\right.$ proteins and $C_{4}$ marine proteins) permitting inferences on the type of energy (carbohydrate-fat) derived from $\mathrm{C}_{3}$ and $\mathrm{C}_{4}$-marine sources.

\section{Results and discussion}

\subsection{Defining Talasiu human diet}

\subsubsection{Collagen data contribution}

All Talasiu samples returned collagen with a yield above $8.7 \mathrm{mg} \cdot \mathrm{g}^{-1}$ (mean $\pm \mathrm{SD}=20.1 \pm 9.9 \mathrm{mg} \cdot \mathrm{g}^{-1}, \mathrm{n}=21$ ) (Table 2). Five samples
(BG2, Sk5, Sk7.1, Sk7.2 and Sk13) were excluded from the dietary interpretation as their $\% \mathrm{C}, \% \mathrm{~N}$ and carbon:nitrogen atomic ratios were outside the 'good' preservation' range (DeNiro, 1985; Ambrose, 1990; van Klinken, 1999). No correlation between carbon and nitrogen isotope ratios and yield, $\% \mathrm{C}, \% \mathrm{~N}$ and $\mathrm{C}: \mathrm{N}$ ratios were found for the 16 other samples indicating that preservation indicator values do not appear to result from taphonomic processes.

Talasiu human collagen $\delta^{13} \mathrm{C}$ values range from -16.8 to $-14.0 \%$, with a mean value of $-15.7 \pm 0.8 \% 0$ and $\delta^{15} \mathrm{~N}$ values vary from 8.8 to $12.1 \%$, with a mean value of $10.7 \pm 0.8 \%$ o $(n=16$, Table 2 , Fig. 2$)$. No significant correlation is observed between carbon and nitrogen ratios indicating a diversified input of food resources based on a differential consumption of $\mathrm{C}_{3}$ and $\mathrm{C}_{4}$-marine proteins as well as high and low trophic level proteins.

The two European contact period pigs of Talasiu display roughly the same isotope ratios with $\delta^{13} \mathrm{C}$ values of -19.8 and $-19.6 \%$ and $\delta^{15} \mathrm{~N}$ values of 7.4 and $8.3 \%$ (Table 2, Fig. 2). Their ratios are in the range of isotope variability described for all Pacific pig values $(-18.6 \pm 1.6 \%$ and $10.2 \pm 1.8 \%, \mathrm{n}=46$ pigs from: Beavan Athfield et al., 2008; Richards et al., 2009; Allen and Craig, 2009; Jones and Quinn, 2009; Valentin et al., 2010; Kinaston et al., 2014). When compared to the two pigs values, the Talasiu human values are more positive for both carbon $(+4.0 \%)$ and nitrogen $(+2.9 \% 0)$. We observe a much higher enrichment in ${ }^{13} \mathrm{C}(+4.0 \%$ versus $0-2 \%$ ) than the expected enrichments between two consecutive trophic levels which are between 0 and to $2 \% 0$ for carbon and 3-6\%o for nitrogen (Bocherens and Drucker, 2003; O'Connell et al., 2012). This observation, confirming a non mono-isotopic human diet, indicates a contribution of dietary resources with isotopic values very different from terrestrial animal isotopic values.

Using the baseline described previously (see previous section, Table 3, Fig. 2) and subtracting from human isotope values the theoretical range of isotopic fractionation from one trophic level to another as proposed by Bocherens and Drucker (2003, between 3 and 5\%), the nitrogen isotope values of Talasiu human diet would have been between 4 and $9 \%$. On the other hand, since carbon isotope spacing has a trophic offset of 0 to $2 \% 0$ and a diet-to-collagen offset of 5\%o (Ambrose and Norr, 1993; Fernandes et al., 2012), carbon isotope values of Talasiu human diet would have been (i) between -18.8 and $-14 \%$ when comparing against bone collagen values, and (ii) between -21.8 and $-19.0 \%$ when comparing against animal flesh and plant values (Fig. 2). These expected human diet values are consistent with the consumption of a mixed diet involving at least three dietary components. The stable carbon isotope ratios demonstrate the complementary contribution of terrestrial resources, including $\mathrm{C}_{3}$-plants and animal 
proteins while the stable nitrogen isotope ratios imply that the Talasiu individuals were sustained by marine resources with a preference for coastal and inshore marine resources (over offshore resources). Therefore, Talasiu collagen results do not meet our first two expectations which suggested a predominate intake of terrestrial food items of low trophic level.

\subsubsection{Apatite data contribution}

Calcium carbonate percentages for the 16 Talasiu individuals with adequately preserved collagen are between 2.8 and $10.2 \%$ (mean $6.8 \pm 1.6 \%, \mathrm{n}=16$ ) (Table 2). Considering that calcium carbonate content in modern bone is between 5 and $6 \%$ (LeGeros and LeGeros, 1984), 8 of the 16 samples presenting values above $6 \%$ would express an excess in carbonate (Table 2) and one sample (BG3), with the value of $2.8 \%$, would indicate a loss of carbonate. The carbonate excess could result either from bioapatite purification pretreatment, incomplete removal of diagenetic carbonate adsorbed on apatite crystal positions or incorporation of diagenetic carbonate. So far, none of the available pretreatments can address this matter (Ambrose et al., 1997). After removing the nine inconsistent samples (Table 2), a Spearman correlation test between $\delta^{13} \mathrm{C}_{\mathrm{ap}}$ and $\mathrm{CaCO}_{3} \%$ did not show a strong correlation, thus rejecting the hypothesis of diagenetic alteration of carbonate in these samples (rho $=0.34, \mathrm{p}<.05, \mathrm{n}=7$ ) (Ambrose et al., 1997: p. 355). In addition, as apatite carbon isotope ratios reflect dietary composition, $\delta^{13} \mathrm{C}_{\mathrm{ap}}$ values should correlate with those of $\delta^{13} \mathrm{C}_{\text {col }}$ (Lee-Thorp et al., 1989; Fernandes et al., 2012). Interestingly, whereas $\delta^{13} \mathrm{C}_{\mathrm{ap}}$ and $\delta^{13} \mathrm{C}_{\mathrm{col}}$ do not show a strong correlation when all samples are examined ( $\mathrm{rho}=0.25, \mathrm{p}>.05, \mathrm{n}=16$ ), thus confirming the possibility of a diagenetic effect, the same test on the reduced dataset (rho $=0.78, \mathrm{p}<.05, \mathrm{n}=7$ ) shows a strong and statistically significant positive correlation that could be interpreted as an indicator of adequate preservation of these apatite samples (Pechenkina et al., 2005).

Talasiu stable carbon isotope ratios of the seven considered samples show $\delta^{13} C_{a p}$ values with a range from -10.9 to $-9.0 \%$ o (mean $\pm \mathrm{SD}=-9.9 \pm 0.6 \%$ o, $\mathrm{n}=7$, Table 2). Applying the carbon isotope diet-apatite spacing (Fernandes et al., 2012), Talasiu human diet values would have been around $\approx-20 \%$. When $\delta^{13} \mathrm{C}_{\mathrm{ap}}$ and $\delta^{13} \mathrm{C}_{\text {col }}$ values are projected in the mono-isotopic model, all individuals are positioned in the left part of the regression lines (Fig. 3). Such a pattern, along the diagonal line from the lower left corner to the upper right corner, suggests an intake of terrestrial $\mathrm{C}_{3}$ and $\mathrm{C}_{4}$-marine foods in all individuals of this subsample, thus supporting the conclusions based on collagen stable isotope results which suggest a mixed diet composed of terrestrial $\mathrm{C}_{3}$ and $\mathrm{C}_{4}$-marine food sources for proteins, carbohydrates and fats.

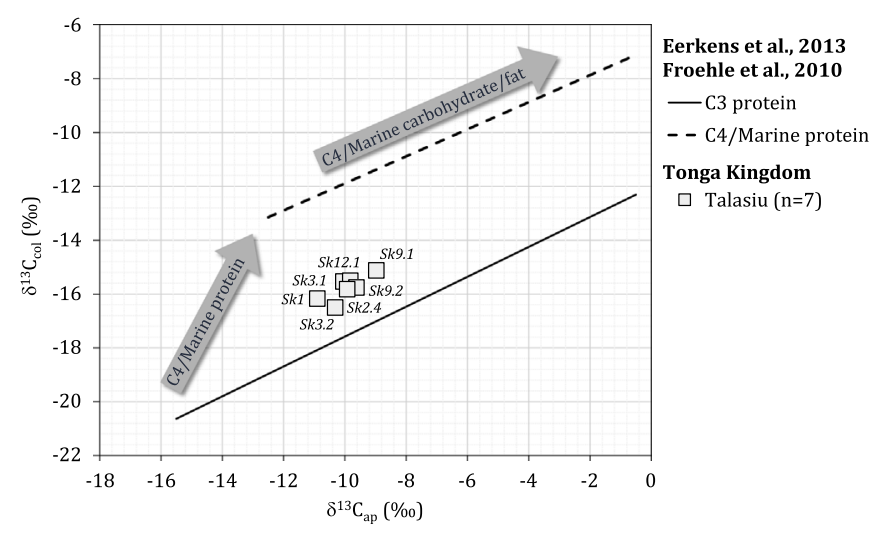

Fig. 3. Modeling collagen and apatite stable carbon isotope ratios for Talasiu individuals (based on model proposed by Froehle et al., 2010 modified by Eerkens et al., 2013).

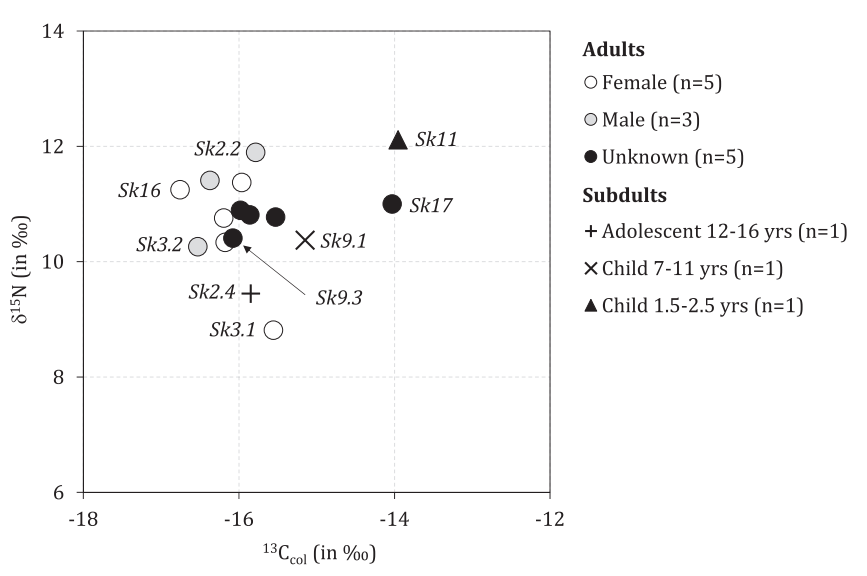

Fig. 4. Collagen $\delta^{13} \mathrm{C}_{\text {col }}$ and $\delta^{15} \mathrm{~N}$ values for all Talasiu humans.

\subsection{Highlighting inter-individual isotope variability}

The Talasiu data indicate a wide variability of collagen stable isotope ratios of $2.8 \%$ for carbon and $3.3 \%$ for nitrogen supporting a heterogeneity of diet among the group (Fig. 4). The three subadults exhibit distinctive $\delta^{13} \mathrm{C}_{\mathrm{col}}$ and $\delta^{15} \mathrm{~N}$ values compared to adults. The youngest child (Sk11), aged between 1.5 and 2.5 years, show the highest $\delta^{13} \mathrm{C}_{\mathrm{col}}$ and $\delta^{15} \mathrm{~N}$ values and the results could favor a hypothesis that he/she was breastfed at the time of death (Katzenberg et al., 1996). The tissue of a breastfed baby can be respectively enriched by $+2-4 \%$ and $1 \%$ in ${ }^{15} \mathrm{~N}$ and ${ }^{13} \mathrm{C}$ during the consumption of the mother's milk (Fogel et al., 1989; Fuller et al., 2006). Other physiological factors related to pathology or stress are also known to increase nitrogen isotope ratios in the consumer's tissue (Katzenberg and Lovell, 1999; Mekota et al., 2006). A moderate consumption of high trophic level proteins can be proposed for the adolescent (Sk2.4, 12-16 years) while the child (Sk9.1, 7-11 years) indicates a higher contribution of marine resources, with non-reef fish.

Two adults display distinctive values. A female (Sk3.1) shows the lowest $\delta^{15} \mathrm{~N}$ value $(8.8 \%$ ) and one unsexed adult (Sk17) has the highest $\delta^{13} \mathrm{C}_{\text {col }}$ value ( $-14 \%$ ). Sk3.1 appears to have mainly focused her diet on food items of low trophic level such as $\mathrm{C}_{3}$-plants and inshore resources while Sk17 appears to have benefited from a diet including higher trophic level marine food such as reef fish. A difference in dietary habits or practices may explain these variations as well as a different geographical origin. One may note that Sk3.1 had lost a large number of teeth before her death and such a masticatory limitation could explain a dietary choice toward food items of low protein content like tubers and fruits. The other adults $(n=11)$ display similar isotope values around $-16 \%$ for carbon and $11 \%$ o for nitrogen. Stable carbon and nitrogen isotope values show no significant difference between males and females in contrast to other prehistoric Pacific communities (Kinaston and Buckley, 2013; Kinaston et al., 2014) (Table 2, Mann-Whitney U Test: $\mathrm{p}\left(\delta^{13} \mathrm{C}\right)=1.000$ and $\left.\mathrm{p}\left(\delta^{15} \mathrm{~N}\right)=0.628\right)$. Individuals from the same burial context, such as Sk2.2/Sk2.4, Sk3.1/Sk3.2 and Sk9.1/Sk9.3 do not display similar isotopic values, suggesting that if they had shared family relationships, they were not accessing the same food items or were eating the same kinds of foods but in different proportions.

The dietary heterogeneity demonstrated by Talasiu individuals (excluding Sk11) is not consistent with our third expectation outlining a dietary focus on certain terrestrial food items. The most parsimonious explanation would be a significant mobility wherein people moved around both within the island and between nearby islands collecting and consuming a range of foods. Different geographical origins have been identified in the raw material of obsidian (north Tonga) and stone artifacts (south and central Tonga and east Fiji) (Reepmeyer et al., 2012; Clark et al., 2014). 
Table 4

Pacific individual series for isotope comparison.

\begin{tabular}{|c|c|c|c|c|c|}
\hline Site & Location & Archaeo. data & Date & N-human & References \\
\hline Watom & Bismarck, Papua New Guinea & & ca. $3000-2800 / 2700-2200 \mathrm{BP}^{\mathrm{a}}$ & 8 & $\begin{array}{l}\text { Petchey and Green, } 2005 \\
\text { Kinaston et al., } 2015\end{array}$ \\
\hline \multirow[t]{2}{*}{ Teouma } & Efate, Vanuatu & Area $2-3$ A-B & ca. $2900 \mathrm{BP}^{\mathrm{b}}$ & 45 & $\begin{array}{l}\text { Valentin et al., } 2010 \\
\text { Kinaston et al., } 2014\end{array}$ \\
\hline & & Area 7C & ca. $2400 \mathrm{BP}^{\mathrm{b}}$ & 6 & Valentin et al., 2014 \\
\hline \multirow[t]{2}{*}{ Uripiv } & Uripiv, Vanuatu & & $2800-2500 \mathrm{BP}$ & 4 & Kinaston et al., 2014 \\
\hline & & & 2500-2000 ВР & 8 & Kinaston et al., 2014 \\
\hline Naitabale & Moturiki, Fiji & & ca. $2700 \mathrm{BP}$ & 1 & Nunn et al., 2007 \\
\hline Olo & Yasawa, Fiji & & ca. $2500 \mathrm{BP}$ & 1 & Petchey et al., 2011 \\
\hline
\end{tabular}

a Petchey et al., 2016.

b Petchey et al., 2014, 2015.

Table 5

Descriptive statistics for human collagen stable isotope ratios of Pacific series and statistics of Kruskal-Wallis test.

\begin{tabular}{|c|c|c|c|c|c|c|c|c|c|}
\hline \multirow[t]{2}{*}{ Site } & \multirow[t]{2}{*}{$\mathrm{n}$} & \multicolumn{4}{|c|}{$\delta^{13} \mathrm{C}(\%)$} & \multicolumn{4}{|c|}{$\delta^{15} \mathrm{~N}(\% 0)$} \\
\hline & & Mean & Min. & Max. & SD & Mean & Min. & Max. & SD \\
\hline $\begin{array}{l}\text { Kruskal-Wallis } \\
\text { test }^{\text {b }}\end{array}$ & & \multicolumn{4}{|l|}{$\mathrm{p}=.000$} & \multicolumn{4}{|c|}{$\mathrm{p}=.000$} \\
\hline Talasiu & 16 & -15.7 & -16.8 & -14.0 & 0.8 & 10.7 & 8.8 & 12.1 & 0.8 \\
\hline Watom $^{\mathrm{a}}$ & 8 & -18.1 & -18.7 & -16.8 & 0.6 & 11.2 & 10.2 & 13.5 & 1.0 \\
\hline Teouma (Lapita) & 45 & -15.5 & -18.2 & -13.6 & 0.9 & 12.2 & 10.4 & 16.1 & 1.0 \\
\hline Teouma 7C & 6 & -19.5 & -19.7 & -19.0 & 0.3 & 8.7 & 8.2 & 9.3 & 0.5 \\
\hline Uripiv $^{\mathrm{a}}$ & 12 & -16.8 & -17.9 & -15.2 & 0.7 & 9.4 & 8.1 & 11.4 & 1.1 \\
\hline Naitabale $^{a}$ & 1 & -15.9 & -15.9 & -15.9 & & 9.5 & 9.5 & 9.5 & \\
\hline $\mathrm{Olo}^{\mathrm{a}}$ & 1 & -15.4 & -15.4 & -15.4 & & 11.1 & 11.1 & 11.1 & \\
\hline All groups & 89 & -16.3 & -19.7 & -13.6 & 1.4 & 11.2 & 8.1 & 16.1 & 1.5 \\
\hline
\end{tabular}

${ }^{\text {a }}$ For references: see Table 4, for individual data see Supplementary material SD2.

${ }^{\mathrm{b}}$ Kruskal-Wallis test were calculated excluding group with $\mathrm{n}<5$.

\subsection{Dietary pattern at Talasiu in comparison with other Pacific islands}

Comparisons between Talasiu individuals and other Lapita, late Lapita and immediately post-Lapita individuals from other coastal environments in the Pacific (Tables 4 and 5, for individual data see SD2): Vanuatu (Valentin et al., 2010, 2014; Kinaston et al., 2014, 2014), Bismarck Islands (Petchey and Green, 2005; Kinaston et al., 2015), and Fiji (Nunn et al., 2007; Petchey et al., 2011) show an overlap of the collagen values, except for the female (Sk3.1), highlighting again her different dietary regime (Fig. 5). Talasiu individuals are similar to the two individuals from Fiji (Naitabale and Olo). However, there are

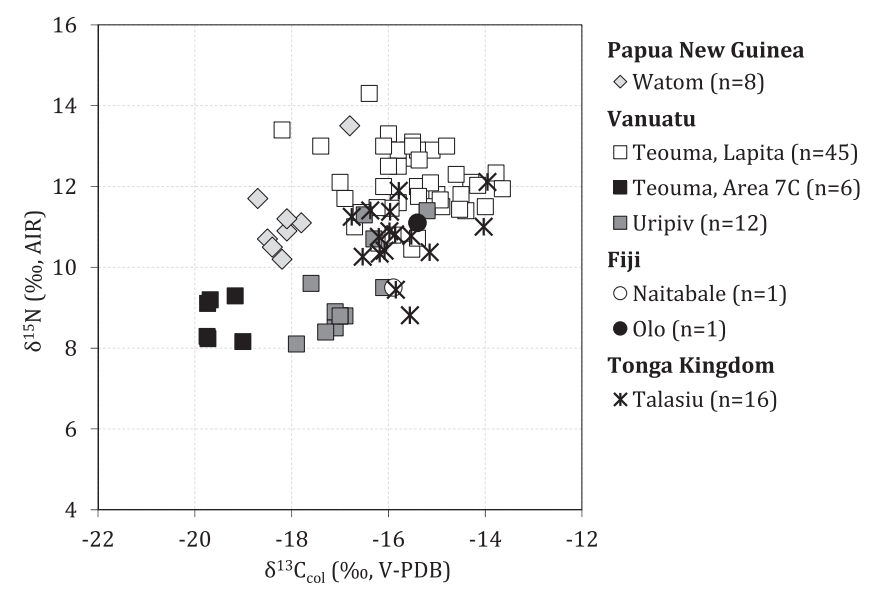

Fig. 5. Collagen $\delta^{13} \mathrm{C}_{\mathrm{col}}$ and $\delta^{15} \mathrm{~N}$ values for Talasiu individuals and other individuals from different locations in the Pacific (see Table 4: Petchey and Green, 2005; Kinaston et al., 2015; Valentin et al., 2010; Kinaston et al., 2014; Valentin et al., 2014; Kinaston et al., 2014; Kinaston et al., 2014; Nunn et al., 2007; Petchey et al., 2011).
Table 6

Mann-Whitney U test for stable carbon and nitrogen collagen ratios between Talasiu and Pacific comparison series.

\begin{tabular}{|c|c|c|c|c|}
\hline & $N-1$ & $\mathrm{~N}-2$ & $\begin{array}{l}2 *(1-p)-p \\
\text { exact }\end{array}$ & $\begin{array}{l}\text { Corrected p- } \\
\text { value }^{\mathrm{a}}\end{array}$ \\
\hline Talasiu/Watom & Talasiu & Watom & & \\
\hline$\delta^{13} \mathrm{C}_{\mathrm{co}}$ & 16 & 8 & 0.000 & .000 \\
\hline$\delta^{15} \mathrm{~N}$ & 16 & 8 & 0.489 & .489 \\
\hline $\begin{array}{c}\text { Talasiu/Teouma } \\
\text { (Lapita) }\end{array}$ & Talasiu & Teouma & & \\
\hline$\delta^{13} \mathrm{C}_{\mathrm{co}}$ & 16 & 45 & 0.224 & .224 \\
\hline$\delta^{15} \mathrm{~N}$ & 16 & 45 & 0.000 & .000 \\
\hline $\begin{array}{l}\text { Talasiu/Teouma } \\
\text { 7C }\end{array}$ & Talasiu & Teouma7C & & \\
\hline$\delta^{13} \mathrm{C}_{\mathrm{co}}$ & 16 & 6 & 0.000 & .000 \\
\hline$\delta^{15} \mathrm{~N}$ & 16 & 6 & 0.000 & .000 \\
\hline Talasiu/Uripiv & Talasiu & Uripiv & & \\
\hline$\delta^{13} \mathrm{C}_{\text {co }}$ & 16 & 12 & 0.000 & .000 \\
\hline$\delta^{15} \mathrm{~N}$ & 16 & 12 & 0.004 & .005 \\
\hline
\end{tabular}

${ }^{a}$ All p-values have been corrected using False Discovery Rate (FDR, Benjamini and Hochberg, 1995) because of multiple comparisons (CRv3.1.1).

significant isotopic differences with the other series (Table 5). Talasiu stable isotope data display significantly higher $\delta^{13} \mathrm{C}_{\text {col }}$ values and similar $\delta^{15} \mathrm{~N}$ values in comparison to the roughly contemporaneous adults from Watom (Bismarck Archipelago) (2700-2200 BP) (Table 6). Talasiu data generally overlap those of the Lapita (ca. 2900 BP) adults from Teouma (Vanuatu), with similar $\delta^{13} \mathrm{C}_{\text {col }}$ values and significantly lower $\delta^{15} \mathrm{~N}$ values (Table 6). $\delta^{13} \mathrm{C}_{\text {col }}$ values suggest a similar $\mathrm{C}_{4}$-marine protein intake at Talasiu and at Teouma (Lapita cemetery) possibly related to exploitation of similar marine environments (Fig. 5). Talasiu individuals display $\delta^{13} \mathrm{C}_{\mathrm{col}}$ and $\delta^{15} \mathrm{~N}$ values significantly higher than the most recent adults from Teouma/7C (ca. 2400 BP) and Uripiv (2500-2000 BP) in Vanuatu (Table 6). Talasiu subadults, similarly to Uripiv subadults (UH8, UH15 and UH27), appear at the margins of the adult isotopic variability (Kinaston et al., 2014).

Significantly, the Talasiu individuals appear to be closer to the Teouma Lapita individuals than to the other individuals involved in the comparison. The relative isotopic position of the Talasiu individuals on the Fig. 5 confirms they had a significant marine resource contribution to their proteinic diet, although lower $\delta^{15} \mathrm{~N}$ values clearly express their dietary preference for inshore resources and reef fish compared to the Teouma Lapita cemetery individuals. The Talasiu people also would demonstrate a lower consumption of horticultural/terrestrial products compared to the later individuals from Teouma/7C (Valentin et al., 2014) and Uripiv (Kinaston et al., 2014). This result is unexpected regarding the general temporal trend toward increasing use of horticulture products in the diet observed across the Pacific area and suggest the influence of specific environmental and biological factors, such as island size, soil fertility and human population size. Field et al. (2009) have proposed that the change toward a richer vegetable diet occurred earlier on the largest island in Fiji. Small island size might have 
influenced rate of diet change at Talasiu, as it is the case for Naitabale and Olo diet which remained marine oriented for longer. However, our comparative results tend to suggest that the observed dietary patterns could equally be linked to other factors in relation to survival behaviors when facing new or changing environments.

\subsection{Dietary pattern at Talasiu and environmental conditions: driving forces}

Could differences in the environmental context at each site be sufficient to explain the diversity of dietary patterns through the Pacific region during the first millennium of human settlement? Our isotopic data, in addition to Talasiu archaeozoological data showing a relatively wide exploitation of inshore resources, including bivalves ( $72 \%$ of total NISP) and inshore reef fish, which point to the high consumption of coastal resources while a decrease in coral reef fish intake would have been expected owing to the fall of the sea-level affecting the lagoon of Fanga 'Uta at the end of Lapita period. On the other hand, our isotope data do not contradict the hypothesis of the use of cultivated plant species and probable inland garden development identified in archaeobotanical data (Ussher, 2015), but if so this was much less than at Uripiv and Watom (Kinaston et al., 2014, 2015). Differences in soil fertility/quality do not seem to be the only force influencing food choices of these early Pacific populations. While the Watom, Uripiv and Teouma sites have fertile metamorphic and volcanic soils, the limestone soils of Tongatapu have been enriched by falls of airborne volcanic ash (Dickinson and Burley, 2007).

Could the Talasiu individuals and the Lapita individuals at Teouma have stable carbon isotope similarities and a propensity for the same food items because they are both maritime colonists? The only difference between the groups is that the Talasiu diet is more focused on inshore resources than the Teouma Lapita diet. This does not contradict the hypothesis that the dietary pattern observed at Talasiu may reflect the behavior of people occupying a place for the first time but suggests the site occupation was prior to the closure of the Fanga'Uta Lagoon around 2500 cal. BP (Ellison, 1988; Spennemann, 1997). However, the similarity in food resources management and consumption observed between Talasiu and Teouma does not support the idea of a 'typical' Lapita diet (Kinaston et al., 2016), considering the temporal lag between Lapita settlers at Teouma (ca. 2900 BP, Petchey et al., 2014, 2015), the founding colony at Nukuleka (2845-2830 cal. BP, Burley et al., 2015) and the Talasiu population settlement (2700-2600 cal. BP).

Finally, in terms of island-human ecosystem dynamics, we propose that dietary differences and the timing of dietary change is likely a function of the existing indigenous biomass on an island/archipelago and of its distribution and density which changed rapidly after human arrival rather than any other environmental factors (Spennemann, 1987). Groups of mobile maritime cultivators may have preferentially used locations where the concentration of wild foods was dense and predictable and did not require much energy to collect. Such concentrations, in places like Tonga where terrestrial resources were limited since the beginning of human occupation, are predominantly shellfish and fish, as illustrated by numerous shell middens bordering the Fanga 'Uta Lagoon on Tongatapu (Clark et al., 2015). The fact that there appears to have been a large 'patch' of shellfish at Talasiu some 200 years after first human arrival is noticeable. It might suggest that the early Tongatapu population was relatively small, while the horticultural development observed at the site represents dietary diversification and might suggest that an expansion in farming and horticultural yields was underway along with associated social and cultural adaptations, particularly the ownership of land.

\section{Conclusion}

The general hypothesis of a dietary shift between early Lapita and late Lapita/immediately post-Lapita periods suggests that the Talasiu people, who date to the transition between the Lapita and Polynesian
Plainware periods (2700-2600 cal. BP, Burley et al., 2015), would have consumed fewer marine resources and more terrestrial resources than the early Lapita people of Teouma in Vanuatu (Valentin et al., 2010, 2014; Kinaston et al., 2014). This assumption is partly supported by the archaeozoological and botanical studies of the Talasiu midden which reflect a broad spectrum subsistence economy that comprised exploitation of lagoon resources including shellfish gathering, and reef and inshore fishing along with the consumption of horticultural products. If stable isotope analyses obtained on Talasiu human collagen $(\mathrm{n}=16)$ and apatite $(\mathrm{n}=7)$ demonstrate a lower intake of high-level trophic marine food fish, it also shows an unexpected persistence in the consumption of marine resources about two centuries after colonization. This pattern suggests a particular human-island ecosystem relationship that may be the result of a small population size and high mobility of human groups. Comparison between different Pacific archipelagos shows that Talasiu individuals were: (1) close to the Lapita individuals of Teouma, even if characterized by a preference for coastal and reef resources, and (2) consumed less horticultural products than the immediately post-Lapita individuals of Teouma (Valentin et al., 2014) and Uripiv (Kinaston et al., 2014). This dietary pattern could indicate that although Talasiu people appear to have had horticultural products, they heavily exploited lagoon resources. By extension, our results suggest the Talasiu people frequented the site before the closing of the Fanga 'Uta lagoon around $2500 \mathrm{cal}$. BP. The Talasiu isotope data, added to those of other sites, will help to confirm if a diet based on both native terrestrial and marine resources is typical of the first colonizers, and if this diet persists in the later population due to the availability of wild resources and size of the human population. This study also concludes that besides environmental factors, other influences, including social and cultural conditions, perhaps related to the small size of a founding community and high population mobility, played an important role in shaping the food practices in early Pacific societies.

\section{Acknowledgments}

We thank the Lapaha Community and Nobles (His Serene Highness Prince Kalaniuvalu Fotofili, Her Serene Highness Princess Marcella Taumoepeau Tupou Kalaniuvalu Fotofili and Her Royal Highness Mele Siu'ilikutapu Kalaniuvalu Fotofili) and the Ministry of Internal Affairs (Government of Tonga). This research including archaeological excavation and isotopic analysis was funded by the MAEDI and CNRS allocated to Frederique Valentin and an Australian Research Council grant to Geoffrey Clark (FT0990591). We would like to thank the National Natural History Museum of Paris (UMR 7209) and Philippe Bearez for access to the fish reference collection.

\section{Appendix A. Supplementary data}

Supplementary data to this article can be found online at https:// doi.org/10.1016/j.jasrep.2018.01.012.

\section{References}

Allen, M.S., Craig, J.A., 2009. Dynamics of Polynesian subsistence: insights from archaeofauna and stable isotopes studies, Aitutaki, Southern Cook Islands. Pac. Sci. 63, 477-506.

Ambrose, S.H., 1990. Preparation and characterization of bone and tooth collagen for isotopic analysis. J. Archaeol. Sci. 17, 431-451.

Ambrose, S.H., 1993. Isotopic analysis of paleodiets: methodological and interpretative considerations. In: Sandford, M.K. (Ed.), Investigation of Ancient Human Tissue. Chemical Analyses in Anthropology. Gordon and Breach Science Publishers, Langhorne, pp. 59-130.

Ambrose, S.H., Butler, B.M., Hanson, D.B., Hunter-Anderson, R.L., Krueger, H.W., 1997. Stable isotopic analysis of human diet in the Marianas archipelago, western Pacific. Am. J. Phys. Anthropol. 104, 343-361.

Ambrose, S.H., Norr, L., 1993. Experimental evidence for the relationship of the carbon isotope ratios of whole diet and dietary protein to those of bone collagen and carbonate. In: Lambert, J.B., Grupe, G. (Eds.), Prehistoric Human Bone Archaeology at the Molecular Level. Springer-Verlag, Berlin, pp. 1-37. 
Anderson, A., 2009. The rat and the octopus: initial human colonization and the prehistoric introduction of domestic animals in remote Oceania. Biol. Invasions 11, 1503-1519.

Beavan Athfield, N., Green, R.C., Craig, J., McFadgen, B., Bickler, S., 2008. Influence of marine sources on ${ }^{14} \mathrm{C}$ ages: isotopic data from Watom island, Papua New Guinea inhumations and pig teeth in light of new dietary standards. J. R. Soc. N. Z. 38, 1-23.

Benjamini, Y., Hochberg, Y., 1995. Controlling the false discovery rate: a practical and powerful approach to multiple testing. J. R. Stat. Soc. Ser. B Stat Methodol. 57, 289-300.

Best, S., 1984. Lakeba: The Prehistory of a Fijian Island (Unpublished PhD thesis) Anthropology Department, University of Auckland.

Bocherens, H., Drucker, D., 2003. Trophic level isotopic enrichment of carbon and nitrogen in bone collagen: case studies from recent and ancient terrestrial ecosystems. Int. J. Osteoarchaeol. 13, 46-53.

Bruzek, J., 2002. A method for visual determination of sex, using the human hip bone. Am. J. Phys. Anthropol. 117, 157-168.

Burley, D., 1999. Lapita settlement to the east: new data and changing perspectives from Ha'apai (Tonga) prehistory. In: Galipaud, J.-C., Lilley, I. (Eds.), Le Pacifique de 5000 à 2000 avant le présent, IRD, Supplements à l'Histoire d'une colonisation, Paris, pp. 189-200.

Burley, D.V., Barton, A., Dickinson, W., Connaughton, S., Taché, K., 2010. Nukuleka as a founder colony for West Polynesian settlement: new insights from recent excavations. Journal of Pacific Archaeology 1, 128-144.

Burley, D., Edinborough, K., Weisler, M., Zhao, J.-X., 2015. Bayesian modeling and chronological precision for Polynesian settlement of Tonga. PLoS One 10, e0120795. http://dx.doi.org/10.1371/journal.pone.0120795.

Clark, G., Anderson, A., 2009. Colonisation and culture change in the early prehistory of Fiji. Terra Australis 31, 407-437.

Clark, G., Grono, E., Ussher, E., Reepmeyer, C., 2015. Early settlement and subsistence on Tongatapu, Kingdon of Tonga: insights from a 2700-2650 cal BP midden deposit. J. Archaeol. Sci. Rep. 3, 513-524.

Clark, G., Petchey, F., Hawkins, S., Reepmeyer, C., Smith, I., Masse, W.B., 2013. Distribution and extirpation of pigs in Pacific islands: a case study from Palau. Archaeol. Ocean. 48, 141-153.

Clark, G., Reepmeyer, C., Melekiola, N., Woodhead, J., Dickinson, W.R., MartinssonWallin, H., 2014. Stone tools from the ancient Tongan state reveal prehistoric interaction centres in the Central Pacific. P. Natl. Acad. Sci. USA 111, 10491-10496.

Cochrane, E., Rivera-Collazo, I., Walsh, E., 2011. New evidence for variation in colonization, cultural transmission, and subsistence from Lapita (2900 BP) to the historic period in Southwestern Fiji. Journal of Pacific Archaeology 2, 40-55.

Collier, S., Hobson, K.A., 1987. The importance of marine protein in the diet of coastal Australian aborigines. Curr. Anthropol. 28, 559-564.

Connaughton, S., Taché, K., Burley, D., 2010. Taupita: a 3000-year-old shell game in the Lapita cultural complex of Tonga. J. Soc. Archaeol. 10, 118-137.

Davidson, J., Leach, F., Sand, C., 2002. Three thousand years of fishing in New Caledonia and the Loyalty islands. In: Bedford, S., Sand, S.C., Burley, D. (Eds.), Fifty Years in the Field: Essays in Honour and Celebration of Richard Shutler Jr's Archaeological Career. New Zealand Archaeological Association Monograph 25, Auckland, pp. 153-164.

DeNiro, M.J., 1985. Post-mortem preservation and alteration of in vivo bone collagen isotope ratios in relation to paleodietary reconstruction. Nature 317, 806-809.

DeNiro, M.J., Epstein, S., 1978. Influence of diet on the distribution of carbon isotopes in animals. Geochim. Cosmochim. Acta 42, 495-506.

DeNiro, M.J., Epstein, S., 1981. Influence of diet on the distribution of nitrogen isotopes in animals. Geochim. Cosmochim. Acta 45, 341-351.

Dickinson, W.R., Burley, D.V., 2007. Geoarchaeology of Tonga: geotectonic and geomorphic controls. Geoarchaeology 22 (2), 229-259.

Drucker, D., Henry-Gambier, D., 2005. Determination of the dietary habits of a Magdalenian woman from Saint-Germain-la-Rivière in southwestern France using stable isotopes. J. Hum. Evol. 49, 19-35.

Eerkens, J.W., Mackie, M., Bartelink, E.J., 2013. Brackish water foraging: isotopic landscapes and dietary reconstruction in Suisun Marsh, Central California. J. Archaeol. Sci. 40, 3270-3281.

Ellison, J.C., 1988. Holocene sea Level Record of Tongatapu, Kingdom of Tonga, from Pollen Analysis of Mangrove Sediments (Unpublished MSc Thesis). Department of Geography, Simon Fraser University, Vancouver.

Fall, P., 2010. Pollen evidence for plant introductions in a Polynesian tropical island ecosystem, Kingdom of Tonga. In: Haberle, S., Stevenson, J., Prebble, M. (Eds.), Altered Ecologies. Fire, Climate and Human Influence on Terrestrial Landscapes, Terra Australis 32. ANU E Press, The Australian National University, Canberra, pp. 257-275.

Fall, P., Drezner, T., 2013. Species origins, dispersal, and island vegetation dynamics in the South Pacific. Ann. Assoc. Am. Geogr. 103, 1041-1057.

Ferembach, D., Schwidetzky, I., Stloukal, M., 1979. Recommandations pour déterminer l'âge et le sexe sur le squelette. BMSAP 6, 7-45.

Fernandes, R., Millard, A.R., Brabec, M., Nadeau, M.-J., Grootes, P., 2014. Food Reconstruction Using Isotopic Transferred Signals (FRUITS): a Bayesian model for diet reconstruction. PLoS One 9 (2), e87436.

Fernandes, R., Nadeau, M.J., Grootes, P.M., 2012. Macronutrient-based model for dietary carbon routing in bone collagen and bioapatite. Archaeol. Anthropol. Sci. 4, 291-301.

Field, J.S., Cochrane, E.E., Greenlee, D.M., 2009. Dietary change in Fijian prehistory: isotopic analyses of human and animal skeletal material. J. Archaeol. Sci. 36, 1547-1556.

Fogel, M.L., Tuross, N., Owsley, D.W., 1989. Nitrogen Isotope Tracers of Human Lactation in Modern and Archaeological Populations. Annual Report of Geophysical Laboratory Carnegie Institution of Washington, pp. 111-117.
Froehle, A.W., Kellner, C.M., Schoeninger, M.J., 2010. FOCUS: effect of diet and protein source on carbon stable isotope ratios in collagen: follow up to Warinner and Tuross (2009). J. Archaeol. Sci. 37, 2662-2670.

Fry, B., Scalan, R., Parker, P., 1983. ${ }^{13} \mathrm{C} /{ }^{12} \mathrm{C}$ ratios in marine food webs of the Torres Strait, Queensland. Mar. Freshw. Res. 34, 707-715.

Fuller, B.T., Fuller, J.L., Harris, D.A., Hedges, R.E.M., 2006. Detection of breastfeeding and weaning in modern human infants with carbon and nitrogen stable isotope ratios. Am. J. Phys. Anthropol. 129, 279-293.

Groube, L.M., 1971. Tonga, Lapita pottery and Polynesian origins. J. Polynesian Soc. 80, 278-316.

Herrscher, E., Le Bras-Goude, G., 2010. Southern French Neolithic populations: isotopic evidence for regional specificities in environment and diet. Am. J. Phys. Anthropol. $141,259-272$.

Howland, M.R., Corr, L.T., Young, S.M., Jones, V., Jim, S., van der Merwe, N.J., Mitchell, A.D., Evershed, R.P., 2003. Expression of the dietary isotope signal in the compoundspecific $\delta^{13} \mathrm{C}$ values of pig bone lipids and amino acids. Int. J. Osteoarchaeol. 13 (1), 54-65.

Hu, Y., Ambrose, S.H., Wang, C., 2006. Stable isotopic analysis of human bones from Jiahu site, Henan, China: implications for the transition to agriculture. J. Archaeol. Sci. 33, 1319-1330.

Iacumin, P., Bocherens, H., Mariotti, A., Longinelli, A., 1996. An isotopic palaeoenvironmental study of human skeletal remains from the Nile Valley. Palaeogeogr. Palaeoclimatol. Palaeoecol. 126, 15-30.

Iacumin, P., Galli, E., Cavalli, F., Cecere, L., 2014. C4-consumers in southern Europe: the case of Fruili V.G. (NE-Italy) during early and central middle ages. Am. J. Phys. Anthropol. 154, 561-574.

Jones, S., Quinn, R., 2009. Prehistoric Fijian diet and subsistence: integration of faunal, ethnographic, and stable isotopic evidence from the Lau Island group. J. Archaeol. Sci. 36, 2742-2754.

Katzenberg, A., 2008. Stable isotope analysis: a tool for studying past diet, demography, and life history. In: Katzenberg, A., Saunders, S.R. (Eds.), Biological Anthropology of the Human Skeleton. John Wiley \& Sons, Inc., pp. 413-441.

Katzenberg, A., Herring, A., Saunders, S.R., 1996. Weaning and infant mortality: evaluating the skeletal evidence. Yearb. Phys. Anthropol. 39, 177-199.

Katzenberg, M.A., Lovell, N.C., 1999. Stable isotope variation in pathological bone. Int. J. Osteoarchaeol. 9, 316-324.

Katzenberg, M.A., Schwarcz, H.P., Knyf, M., Melbye, F.J., 1995. Stable isotope evidence for maize horticulture and palaeodiet in Southern Ontario, Canada. Am. Antiq. 60, 335-350.

Keegan, W.F., DeNiro, M.J., 1988. Stable carbon- and nitrogen-isotope ratios of bone collagen used to study coral-reef and terrestrial components of prehistoric Bahamian diet. Am. Antiq. 53, 320-336.

Kellner, C.M., Schoeninger, M.J., 2007. A simple carbon isotope model for reconstructing prehistoric human diet. Am. J. Phys. Anthropol. 133, 1112-1127.

Kennett, D., Anderson, A., Winterhalder, B., 2006. The ideal free distribution, food production, and the colonization of Oceania. In: Kennett, D., Winterhalder, B. (Eds.), Behavioral Ecology and the Transition to Agriculture. University of California Press, Berkeley, pp. 265-288.

Kinaston, R.L., Anson, D., Petchey, P., Walter, R., Robb, K., Buckley, H., 2015. Lapita diet and subsistence strategies on Watom Island, Papua New Guinea: new stable isotope evidence from humans and animals. Am. J. Phys. Anthropol. 157, 30-41.

Kinaston, R., Bedford, S., Richards, M., Hawkins, S., Gray, A., Jaouen, K., Valentin, F., Buckley, H., 2014. Diet and human mobility from the Lapita to the Early Historic Period on Uripiv Island, northeast Malakula, Vanuatu. PLoS One 9, e104071.

Kinaston, R.L., Bedford, S.B., Spriggs, M., Anson, D., Buckley, H., 2016. Is there a 'Lapita diet'? A comparison of Lapita and post-Lapita skeletal samples from four Pacific island archaeological sites. In: Oxenham, M., Buckley, H. (Eds.), The Routledge Handbook of Bioarchaeology in Southeast Asia and the Pacific. Taylor \& Francis Group, pp. 427-461.

Kinaston, R.L., Buckley, H.R., 2013. The Stable Isotope Analysis of Prehistoric Human Diet in the Pacific Islands With an Emphasis on Lapita. 25. University of Otago studies in Archaeology, pp. 91-107.

Kinaston, R.L., Buckley, H.R., Valentin, F., Bedford, S., Spriggs, M., Hawkins, S., Herrscher, E., 2014. Lapita diet in remote Oceania: new stable isotope evidence from the 3000-year-old Teouma site, Efate Island, Vanuatu. PLoS One 9, e90376.

Kirch, V., 2002. On the Road on the Winds. An Archaeological History of the Pacific Islands Before European Contact, 2nd edition. University of California Press, London.

van Klinken, G.J., 1999. Bone collagen quality indicators for palaeodietary and radiocarbon measurements. J. Archaeol. Sci. 26, 687-695.

Leach, B.F., Quinn, C.J., Lyon, G.L., 1996. A stochastic approach to the reconstruction of prehistoric human diet in the Pacific region from bone isotope signatures. Records of the Museum of New Zealand Te Papa Tongarewa 8, 1-54.

Lee-Thorp, J., Sponheimer, M., 2003. Three case studies used to reassess the reliability of fossil bone and enamel isotope signals for paleodietary studies. J. Anthropol. Archaeol. 22, 208-216.

Lee-Thorp, J., Sponheimer, M., van der Merwe, A.E., 1989. Stable carbon isotope ratio differences between bone-collagen and bone apatite, and their relationship to diet. J. Archaeol. Sci. 16, 585-599.

LeGeros, R., LeGeros, J., 1984. Phosphate minerals in human tissues. In: Nriagu, J., Moore, P. (Eds.), Phosphate Minerals. Springer-Verlag, Berlin, pp. 351-385.

Mekota, A.-M., Grupe, G., Ufer, S., Cuntz, U., 2006. Serial analysis of stable nitrogen and carbon isotopes in hair: monitoring starvation and recovery phases of patients suffering from anorexia nervosa. Rapid Commun. Mass Spectrom. 20, 1604-1610.

Nunn, P.D., Carson, M.T., 2015. Sea-level fall implicated in profound societal change about 2570 cal. yr BP (620 BC) in western Pacific island groups. Geo: Geography and Environment 2, 17-32. 
Nunn, P.D., Ishimura, T., Dickinson, W.R., Katayama, K., Thomas, F., Kumar, R., Matararaba, S., Davidson, J., Worthy, T., 2007. The Lapita occupation at Naitabale, Moturiki Island, Central Fiji. Asian Perspect. 46, 96-132.

O'Connell, T.C., Hedges, R.E.M., 1999. Investigations into the effect of diet on modern human hair isotopic values. Am. J. Phys. Anthropol. 108, 409-425.

O'Connell, T.C., Kneale, C.J., Tasevska, N., Kuhnle, G.G.C., 2012. The diet-body offset in human nitrogen isotopic values: a controlled dietary study. Am. J. Phys. Anthropol. 149, 426-434.

Pechenkina, E.A., Ambrose, S.H., Xiaolin, M., Benfer, R.A., 2005. Reconstructing northern Chinese Neolithic subsistence practices by isotopic analysis. J. Archaeol. Sci. 32, 1176-1189.

Petchey, P., Buckley, H., Walter, R., Anson, D., Kinaston, R., 2016. The 2008-2009 excavations at the SAC locality, Reber-Rakival Lapita site, Watom Island, Papua New Guinea. The Journal of Indo-Pacific Archaeology 40, 12-31.

Petchey, F., Clark, G., 2011. Tongatapu hardwater: investigation into the ${ }^{14} \mathrm{C}$ marine reservoir offset in lagoon, reef and open ocean environments of a limestone island. Quat. Int. 6, 539-549.

Petchey, F., Green, R.C., 2005. Use of three isotopes to calibrate human bone radiocarbon determinations from Kainapirina (SAC), Watom Island, Papua New Guinea. Radiocarbon 47, 181-192.

Petchey, F., Spriggs, M., Bedford, S., Valentin, F., 2015. The chronology of occupation at Teouma, Vanuatu: use of a modified chronometric hygiene protocol and Bayesian modeling to evaluate midden remains. J. Archaeol. Sci. Rep. 4, 95-105.

Petchey, F., Spriggs, M., Bedford, M., Valentin, F., Buckley, H.R., 2014. Radiocarbon dating of burials from the Teouma Lapita cemetery, Efate, Vanuatu. J. Archaeol. Sci. 50, 227-242.

Petchey, F., Spriggs, M., Leach, F., Seed, M., Sand, C., Pietrusewsky, M., Anderson, K., 2011. Testing the human factor: radiocarbon dating the first peoples of the South Pacific. J. Archaeol. Sci. 38, 29-44.

Poulsen, J., 1987. Early Tongan Prehistory. Volumes 1 and 2 Terra Australis 12, Department of Prehistory, Research School of Pacific Studies, Canberra.

Reepmeyer, C., Clark, G., Sheppard, P., 2012. Obsidian source use in Tongan prehistory: new results and implications. Journal of Island and Coastal Archaeology 7, 255-271.

Richards, M., West, E., Rolett, B., Dobney, K., 2009. Isotope analysis of human and animal diets from the Hanamiai archaeological site (French Polynesia). Archaeol. Ocean. 44, 29-37.

Salesse, K., Dufour, E., Lebon, M., Wurster, C., Castex, D., Bruzek, J., Zazzo, A., 2014. Variability of bone preservation in a confined environment: the case of the catacomb of Sts Peter and Marcellinus (Rome, Italy). Palaeogeogr. Palaeoclimatol. Palaeoecol. 416, 43-54.

Scheuer, L., Black, S., 2000. Developmental juvenile osteology. Elsevier Academic Press, Oxford.

Schoeninger, M.J., 2010. Diet reconstruction and ecology using stable isotope ratios. In: Larsen, C.S. (Ed.), A Companion to Biological Anthropology. Wiley-Blackwell, Oxford, UK, pp. 445-464.

Schoeninger, M.J., De Niro, M.J., Tauber, H., 1983. Stable nitrogen isotope ratios of bone collagen reflect marine and terrestrial components of prehistoric human diet. Science 220, 1381-1383.

Schoeninger, M.J., DeNiro, M.J., 1984. Nitrogen and carbon isotopic composition of bone collagen from marine and terrestrial animals. Geochim. Cosmochim. Acta 48, 625-639.

Schwarcz, H.P., 2000. Some biochemical aspects of carbon isotopic paleodiet studies. In: Ambrose, S.H., Katzenberg, M.A. (Eds.), Biogeochimical Approaches to Paleodietary Analysis. Kluwer Academic/Plenum Publishers, New York, pp. 189-211.

Sheppard, P., 2011. Lapita colonization across the near/remote Oceania boundary. Curr. Anthropol. 52 (6), 799-840.

Skoglund, P., Posth, C., Sirak, K., Spriggs, M., Valentin, F., Bedford, S., Clark, G.R., Reepmeyer, C., Petchey, F., Fernandes, D., Fu, Q., Harney, E., Lipson, M., Mallick, S., Novak, M., Rohland, N., Stewardson, K., Abdullah, S., Cox, M.P., Friedlaender, F.R., Friedlaender, J.S., Kivisild, T., Koki, G., Kusuma, P., Merriwether, D.A., Ricaut, F.-X., Wee, J.T.S., Patterson, N., Krause, J., Pinhasi, R., Reich, D., 2016. Genomic insights into the peopling of the Southwest Pacific. Nature 538, 510-513. http://dx.doi.org/ 10.1038/nature1984.
Spennemann, D.H.R., 1987. Availability of shellfish resources on prehistoric Tongatapu, Tonga: effects of human predation and changing environment. Archaeol. Ocean. 22, 81-96.

Spennemann, D.H.R., 1993. Cowrie tools: fact or fiction? Archaeol. Ocean. 28, 40-49. Spennemann, D.H.R., 1997. A Holocene sea-level history for Tongatapu, Kingdom of Tonga. In: Sherwood, A.M. (Ed.), Coastal and Environmental Geoscience Studies of the Southwest Pacific Islands, SOPAC Technical Bulletin 9, pp. 115-151.

Stantis, C., Kinaston, R., Richards, M.P., Davidson, J.M., Buckley, H.R., 2015. Assessing human diet and movement in the Tongan maritime chiefdom using isotopic analyses. PLoS One 10, e0123156.

Storey, A.A., Spriggs, M., Bedford, S., Hawkins, S.C., Robins, J.H., Huynen, L., MatisooSmith, E., 2010. Mitochondrial DNA from 3000-year old chickens at the Teouma site, Vanuatu. J. Archaeol. Sci. 37, 2459-2468.

Summerhayes, G.R., Matisoo-Smith, E., Mandui, H., Allen, J., Specht, J., Hogg, N., McPherson, S., 2010. Tamuarawai (EQS): an early Lapita site on Emirau, New Ireland, PNG. Journal of Pacific Archaeology 1 (1), 62-75.

Twiss, K., 2012. The archaeology of food and social diversity. J. Archaeol. Res. 20, 357-395.

Tykot, R.H., Falabella, F., Planella, M.T., Aspillaga, E., Sanhueza, L., Becker, C., 2009. Stable isotopes and archaeology in central Chile: methodological insights and interpretative problems for dietary reconstruction. Int. J. Osteoarchaeol. 19 (2), 156-170.

Ubelaker, D.H., 1989. Human Skeletal Remain Excavation, Analysis, Interpretation. Taraxacum, Washington DC.

Ussher, E., 2015. Agricultural Development in Tongan Prehistory: An Archaeobotanical Perspective (Unpublished $\mathrm{PhD}$ thesis). The Australian National University.

Valentin, F., Bocherens, H., Gratuze, B., Sand, C., 2006. Dietary patterns during the late prehistoric/historic period in Cikobia island (Fiji): insights from stable isotopes and dental pathologies. J. Archaeol. Sci. 33, 1396-1410.

Valentin, F., Buckley, H.R., Herrscher, E., Kinaston, R.L., Bedford, M., Spriggs, M., Hawkins, S., Neal, K., 2010. Lapita subsistence strategies and food consumption patterns in the community of Teouma (Efate,Vanuatu). J. Archaeol. Sci. 37, 1820-1829.

Valentin, F., Clark, G., 2013. Early Polynesian mortuary behaviour at the Talasiu site Kingdom of Tonga. Journal of Pacific Archaeology 4, 1-14.

Valentin, F., Détroit, F., Sprigg, M.J.T., Bedford, S., 2016. Early Lapita skeletons from Vanuatu show Polynesian craniofacial shape: implications for remote oceanic settlement and Lapita origins. Proc. Natl. Acad. Sci. U. S. A. 113 (2), 292-297.

Valentin, F., Herrscher, E., Bedford, S., Spriggs, M., Buckley, H.R., 2014. Evidence for social and cultural change in central Vanuatu between 3000 and 2000 BP: comparing funerary and dietary patterns of the first and later generations at Teouma, Efate. The Journal of Island and Coastal Archaeology 9, 381-399.

Warinner, C., Tuross, N., 2009. Alkaline cooking and stable isotope tissue-diet spacing in swine: archaeological implications. J. Archaeol. Sci. 36 (8), 1690-1697.

White, A.W., Worthy, T., Hawkins, S., Bedford, S., Spriggs, M., 2010. Megafaunal meiolaniid horned turtles survived until early human settlement in Vanuatu, Southwest Pacific. Proc. Natl. Acad. Sci. U. S. A. 107, 15512-15516.

Williams, J.S., White, C.D., Longstaffe, F.J., 2005. Trophic level and macronutrient shift effects associated with the weaning process in the postclassic Maya. Am. J. Phys. Anthropol. 128, 781-790.

Wong, M.B., 2014. A Dietary Isotopic Study at Nukuleka, Tonga. Anthropology Dpt, The University of British Columbia, Vancouver (38 np).

Wright, L.E., Schwarcz, H.P., 1996. Infrared and isotopic evidence for diet diagenesis of bone apatite at Dos Pilas, Guatemala: palaeodietary implications. J. Archaeol. Sci. 23, 933-944.

Yoneda, M., Suzuki, R., Shibata, Y., Morita, M., Sukegawa, T., Shigehara, N., Akazawa, T., 2004. Isotopic evidence of inland-water fishing by a Jomon population excavated from the Boji site, Nagano Japan. J. Archaeol. Sci. 31, 97-107.

Zazzo, A., 2014. Bone and enamel carbonate diagenesis: a radiocarbon prospective. Palaeogeogr. Palaeoclimatol. Palaeoecol. 416, 168-178.

Zazzo, A., Munoz, O., Saliège, J.-F., 2014. Diet and mobility in a late Neolithic population of coastal Oman inferred from radiocarbon dating and stable isotope analysis. Am. J. Phys. Anthropol. 153 (3), 353-364. 